\title{
Cerebral schistosomiasis mansoni
}

\section{Esquistossomose mansônica cerebral}

José Roberto Lambertucci ${ }^{1}$, Izabela Voieta ${ }^{1}$ and Izabela dos Santos Silveira ${ }^{2}$

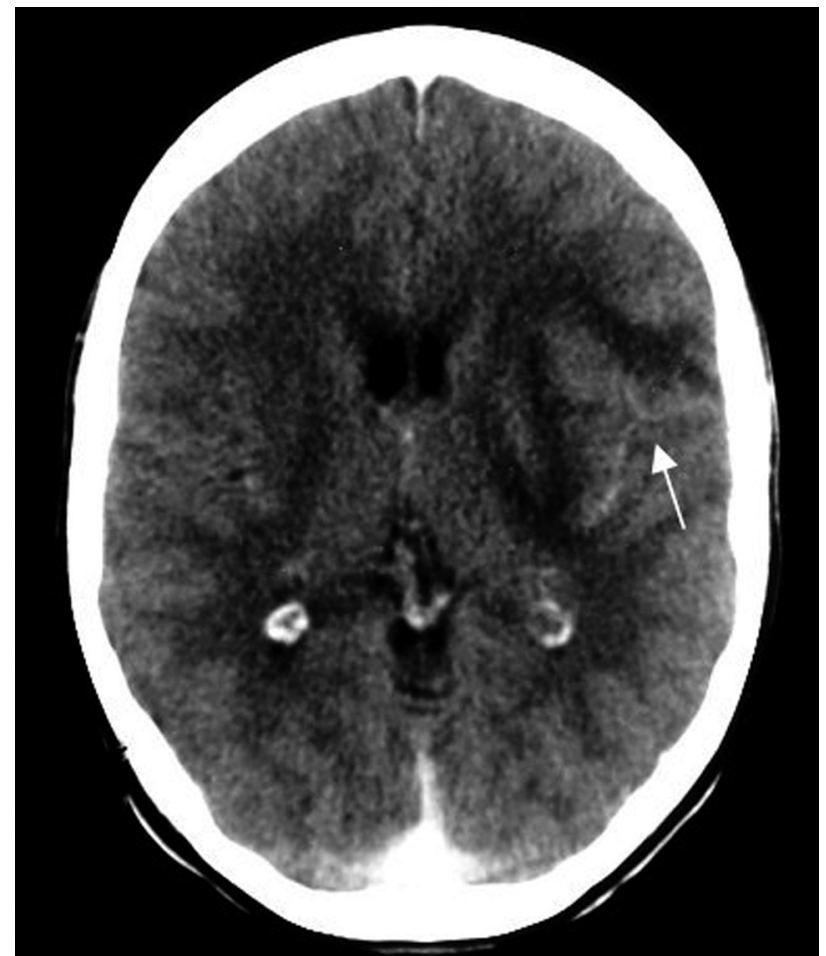

A

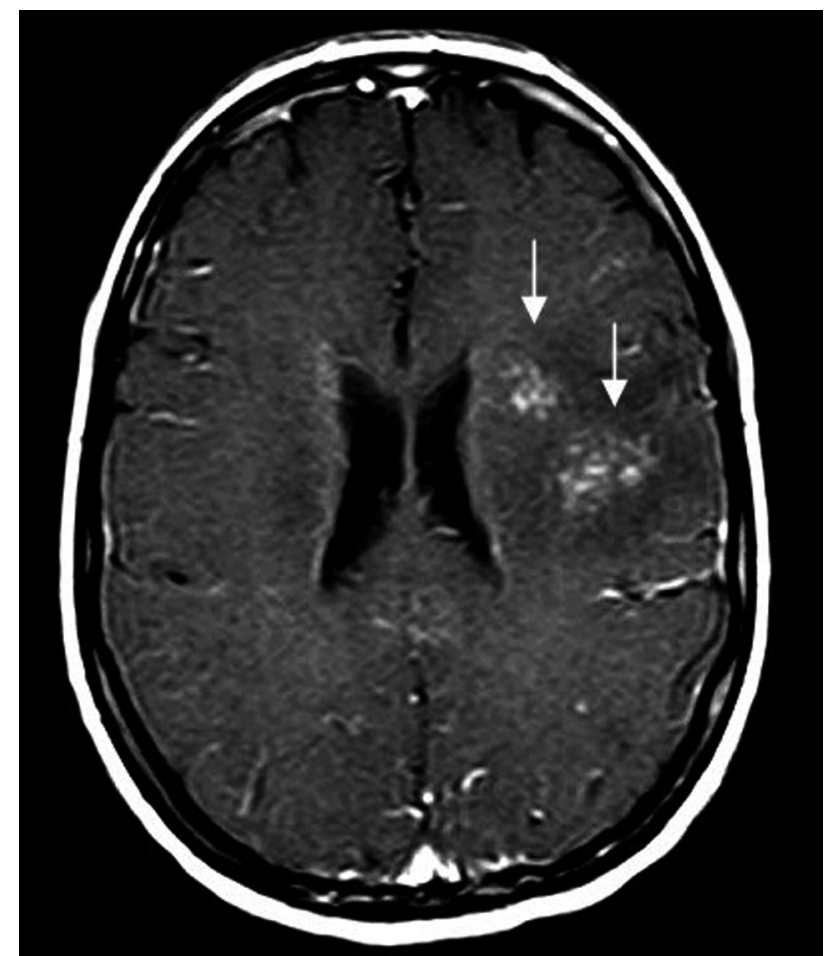

B

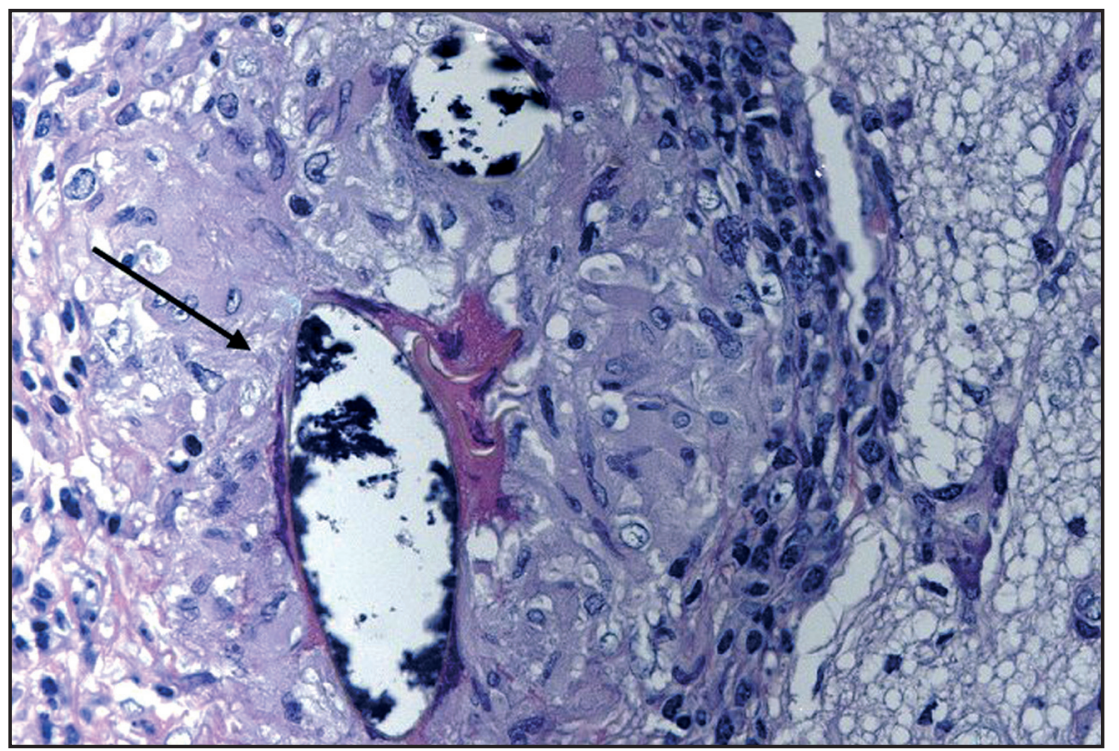

C

1. Curso de Pós-Graduação em Ciências da Saúde: Infectologia e Medicina Tropical, Faculdade de Medicina, Universidade Federal de Minas Gerais, Belo Horizonte, MG, 2. Serviço de Anatomia Patológica, Faculdade de Medicina, Universidade Federal de Minas Gerais, Belo Horizonte, MG.

Address to: Dr. José Roberto Lambertucci. Faculdade de Medicina/UFMG. Av. Alfredo Balena 190, 30130-100 Belo Horizonte, MG, Brasil.

email: lamber@uai.com.br

Recebido para publicação em 03/11/2008

Aceito em 10/11/2008 
A 26-year-old woman reported a history of severe headache followed by seizures five days before being admitted to hospital. She was first examined by a physician in her town in the northeast of Minas Gerais (Brazil), who diagnosed anxiety and prescribed benzodiazepine. Since the seizures persisted, her family decided to bring her to a specialized health center in Belo Horizonte, to seek proper diagnosis and treatment. In our hospital, a computed tomograph (CT) scan of the brain showed a contrast-enhanced tumor mass in the left parietal and frontal lobes, surrounded by edema (Figure A - arrow). Axial contrast-enhanced T1-weighted MR imaging showed a focal multinodular pattern (Figure B - arrows) ${ }^{3}$. A biopsy fragment from the brain tumor, examined under optical microscopy (H\&E 400x), revealed the presence of Schistosoma mansoni egg shells surroundedbyproliferativegranulomata (Figure C-arrow) ${ }^{2}$. She was started on schistosomiasis treatment with praziquantel (60 $\mathrm{mg} / \mathrm{kg}$ of body weight, in a single dose), followed by prednisone $(80 \mathrm{mg} /$ day $)$ for seven days to treat the cerebral edema. She was discharged from hospital 10 days later in a good general condition. Two months later, she was reexamined at the outpatient clinic and was found to be asymptomatic. No motor or sensory sequelae were caused by the biopsy or the brain tumor. After the treatment with diphenyl hydantoin was started, there were no reports of seizures.

A paciente, de 26 anos, informava história de forte dor de cabeça, seguida de convulsões, cinco dias antes da admissão hospitalar. Ela foi examinada pelo médico de sua cidade no nordeste de Minas Gerais (Brasil) que diagnosticou ansiedade e prescreveu um benzodiazepínico. Como as convulsões persistiram, a família decidiu trazê-la para centro de saúde especializado de
Belo Horizonte em busca de diagnóstico e tratamento adequados. Em nosso hospital, uma tomografia computadorizada do cérebro mostrou massa tumoral localizada nos lobos frontal e parietal à esquerda, acentuada pelo contraste e envolvida por edema (Figura A - seta). A ressonância magnética, ponderada em T1, em corte axial, mostrou lesão com padrão multinodular em focos, que era acentuada pelo contraste (Figura B - setas) ${ }^{3}$. No exame do fragmento obtido por biópsia cerebral, à microscopia óptica (H\&E 400X), observaram-se cascas de ovos de Schistosoma mansoni envolvidas por granulomas em fase proliferativa (Figura $\mathrm{C}$ - seta) ${ }^{2}$. Iniciou-se o tratamento da esquistossomose com praziquantel (60mg/kg de peso, em dose única), seguido de prednisona para o edema cerebral ( $80 \mathrm{mg} / \mathrm{dia}$, por sete dias) e a paciente deixou o hospital 10 dias depois em bom estado geral. Dois meses mais tarde, quando re-examinada em ambulatório, encontrava-se assintomática. Nenhuma seqüela motora ou sensitiva foi provocada pela biópsia ou pelo tumor. Após o início do tratamento, com difenil-hidantoína não houve relato de convulsões.

\section{REFERENCES}

1. Braga BP, Costa Junior LB, Lambertucci JR. Magnetic resonance imaging of cerebellar schistosomiasis mansoni. Revista da Sociedade Brasileira de Medicina Tropical 36: 635-636, 2003

2. Lambertucci JR, Silva LC, Amaral RS. Guidelines for the diagnosis and treatment of schistosomal myeloradiculopathy. Revista da Sociedade Brasileira de Medicina Tropical 40: 574-581, 2007.

3. Sanelli PC, Lev MH, Gonzalez RG, Schaefer PW. Unique linear and nodular MR enhancement pattern in schistosomiasis of the central nervous system: report of three patients. AJR American Journal of Roentgenology 177: 1471-1474, 2001 